\title{
Factors Associated with Fusarium Crown and Root Rot of Asparagus Outbreaks in Quebec
}

\author{
Chantal Hamel, Vladimir Vujanovic, Aiko Nakano-Hylander, Richard Jeannotte, and Marc St-Arnaud
}

First author: Environmental Health/Water and Nutrients, Agriculture and Agri-Food Canada, 1 Airport Road Box 1030, Swift Current (SK) S9H 2X3 Canada; second and fifth authors: Institut de recherche en biologie végétale, Université de Montréal and Jardin botanique de Montréal, 4101 Sherbrooke est, Montréal (QC) H1X 2B2 Canada; and third and fourth authors: Natural Resource Sciences, Macdonald Campus of McGill University, 21111 Lakeshore Road, Ste-Anne-de-Bellevue (QC) H9X 3V9 Canada.

Current address of A. Nakano-Hylander: Microbial Ecology, Ecology Building, Lund University, SE-223 62 Lund, Sweden.

Accepted for publication 21 March 2005.

\begin{abstract}
Hamel, C., Vujanovic, V., Nakano-Hylander, A., Jeannotte, R., and St-Arnaud, M. 2005. Factors associated with Fusarium crown and root rot of asparagus outbreaks in Quebec. Phytopathology 95:867-873.

The Fusarium spp. causing Fusarium crown and root rot (FCRR) are ubiquitous and abundant in soils, but in contrast, disease expression is localized and sporadic. Previous studies have related FCRR infection to phenolic acids released by asparagus, to the repression of Mn-reducers in soil, and to various soil physicochemical conditions. Fifty commercial asparagus plantations were surveyed using an exploratory approach in order to pinpoint the ecological conditions associated with FCRR devel-

conditions and percentage of field area affected by FCRR varied widely between asparagus plantations. Planting depth was positively correlated with percentage of field area affected by FCRR and, hence, deep planting may favor FCRR infection. Plantation age was positively correlated with percentage of field area affected by FCRR, while soil available Mn was inversely correlated. Most importantly, soil Mn availability decreased with increasing plantation age, supporting the hypothesis of an asparagusmediated negative impact on Mn-reducing bacteria and of the involvement of reduced Mn availability in FCRR development. Improving the availability of $\mathrm{Mn}$ could provide a solution to the problem of FCRR in asparagus plantations.
\end{abstract} opment. Twenty-eight variables were used to describe the soil environments of the asparagus crops as well as the influence of crop management practices used locally. The data set was analyzed both as a whole and parsed by main cultivars (Jersey Giant and Guelph Millenium). Both field
Additional keywords: Asparagus officinalis, crop management factor, ecology of disease expression, soil available manganese, soil quality.
Asparagus (Asparagus officinalis L.) plantations can be utilized for 15 years and sometimes longer, depending on the resilience of the plantation to Fusarium crown and root rot (FCRR). The presence of this disease in plantations markedly reduces the profitability of the crop. Fusarium spp. are ubiquitous in soils where they cause damping-off of newly emerged seedlings, wilt, and crown and root rots in different crops (18). In asparagus, the disease is caused by a complex of Fusarium spp. including F. proliferatum (T. Matsush.) Nirenberg, F. culmorum (W. G. Sm.), F. oxysporum (Schlenchtend):Fr. f. sp. asparagi Cohen \& Heald $(8,9)$, and F. redolens Wollenw. f. sp. asparagi Baayen (1). Reddish lesions develop at the base of stems followed by yellowing and death of the ferns. Depopulated areas in asparagus fields are the typical expression of FCRR occurrence (10).

In contrast to the ubiquity of Fusarium spp. in soils, the incidence of FCRR is localized and sporadic suggesting that a set of ecological conditions influences disease development. Information on the ecological conditions associated with the expression of FCRR is sparse. Nonnecke (19) reported that low soil pH and fine-textured soil, or inadequate drainage favor the disease. In a survey of the ecological conditions associated with healthy and infested asparagus plantations, high soil organic matter, high soil water holding capacity, and in contrast to Nonnecke (19), high

Corresponding author: C. Hamel; E-mail address: HamelC@ agr.gc.ca

DOI: 10.1094/PHYTO-95-0867

This article is in the public domain and not copyrightable. It may be freely reprinted with customary crediting of the source. The American Phytopathological Society, 2005. clay content were associated with low disease incidence except when drainage was poor (11). In the same study, magnesium $(\mathrm{Mg})$ appeared to be the only deficient nutrient in infested fields and this condition was associated with high soil potassium $(\mathrm{K})$ to $\mathrm{Mg}$ ratio. In agreement with Nonnecke (19), conducive sites had a low soil pH. Gehlker and Scholl (11) concluded that FCRR disease in asparagus was provoked by several soil-related factors with negative impact on plant growth, which could be acting either independently or in combination. Asparagus plants weakened by stresses related to nutrients, water, harvest, or other factors may be more susceptible to infection, but certain ecological conditions may also be conducive to increased aggressiveness of indigenous Fusarium populations, which would lead to disease outbreaks. Sodium chloride $(\mathrm{NaCl})$ is known to reduce the severity of FCRR $(7,21)$, and it was proposed that the positive effect of $\mathrm{NaCl}$ was due to a plant-mediated stimulation of manganese (Mn) reducing bacteria, which would, in turn, increase soil $\mathrm{Mn}$ availability in asparagus plantation soils (21). Application of $\mathrm{NaCl}$ resulted in increased $\mathrm{Na}$ and decreased $\mathrm{Mg}$ and calcium $(\mathrm{Ca})$ concentrations in asparagus tissues (27) suggesting that the effect of $\mathrm{NaCl}$ could also be physiological. However, in a split root experiment, disease suppression was stronger where $\mathrm{NaCl}$ was applied (10). This suggests that the impact of $\mathrm{NaCl}$ is not, or is not only plant-mediated, but is also soil-mediated, although the amount of $\mathrm{NaCl}$ used was apparently too low to have fungicidal activity.

Resolving the complexity of the soil-Fusarium-asparagus interactions may promote the development of methods to control FCRR. Therefore, a multidisciplinary study was undertaken to improve our understanding of FCRR in the province of Quebec, Canada. An improved selective medium for the isolation of 
Fusarium species from asparagus fields (25) and a culture-independent molecular fingerprinting approach to assess Fusarium diversity (29) were developed. The distribution in soil and plant parts of 16 Fusarium taxa isolated during the survey, and the diversity of their populations, as affected by geographic localization is reported elsewhere (26). The analysis of the relation between FCRR and soil-microbiological variables revealed a microbial community structure reorganization occurring concurrently with the development of FCRR (12). The objective of the present paper was to identify the soil physicochemical conditions and management variables that may favor or suppress FCRR expression.

\section{MATERIALS AND METHODS}

Experimental conditions. Fifty commercial asparagus fields were sampled during the last 2 weeks of June 2001, which corresponded to the end of the asparagus-harvesting season in Quebec, Canada. The fields were located in four regions of Southern Quebec, namely Quebec City, Trois-Rivières, L'Assomption, and St-Hyacinthe. Information on crop management practices (Table 1) was obtained from growers via a survey completed with the assistance of local agronomists. Physicochemical characteristics of soil from the asparagus fields were determined (Tables 1 and $2)$. The cultivars planted in the fields studied were Guelph Millenium (13 fields), Jersey Giant (15 fields), Viking KB3 (4 fields), Lucullus (2 fields), Jersey Knight (4 fields), Mary Washington (1 field), and SYN-456 (5 fields). Cultivar identity was uncertain in seven fields. Plantation age spanned from 1 to 21 years.

TABLE 1. Characteristics of the asparagus plantations surveyed

\begin{tabular}{|c|c|c|c|c|}
\hline Parameters & Median & Mean & Min. & Max. \\
\hline Area affected $(\%)$ & 10.0 & 12.3 & $<0.1$ & 65.0 \\
\hline $\mathrm{N}$-fertilization rate $\left(\mathrm{kg} \mathrm{N} \mathrm{ha}^{-1}\right)^{\mathrm{a}}$ & 95 & 83.1 & 0.0 & 147.5 \\
\hline P-fertilization rate $\left(\mathrm{kg} \mathrm{P}_{2} \mathrm{O}_{5} \mathrm{ha}^{-1}\right)^{\mathrm{a}}$ & 55.0 & 57.0 & 0.0 & 125.0 \\
\hline $\mathrm{K}$-fertilization rate $\left(\mathrm{kg} \mathrm{K}_{2} \mathrm{O} \mathrm{ha}^{-1}\right)^{\mathrm{a}}$ & 75.0 & 82.9 & 0.0 & 186.0 \\
\hline Harvest length (day) & 36.0 & 33.2 & 0.0 & 60.0 \\
\hline Yield ( $\mathrm{kg}$ fresh weight $\mathrm{ha}^{-1}$ ) & 1,500 & 1,720 & 0 & 5,000 \\
\hline Length of spears harvested $(\mathrm{cm})$ & 21.5 & 21.5 & 20 & 26 \\
\hline Row spacing (m) & 1.5 & 1.4 & 0.3 & 1.8 \\
\hline Planting depth $(\mathrm{cm})$ & 20.0 & 21.8 & 15.0 & 31.0 \\
\hline Tillage depth $(\mathrm{cm})$ & 5.0 & 4.6 & 0.0 & 15.0 \\
\hline Area in cultivation (ha) & 1.2 & 3.3 & $<0.1$ & 23.0 \\
\hline Plantation age (year) & 5.0 & 7.5 & 1.0 & 21.0 \\
\hline
\end{tabular}

a Forty-three asparagus plantations were surveyed. Sixteen fields receiving organic fertilization were excluded from this group because the amount of nutrients provided by the organic amendments was unknown.
Sampling and analysis. The Quebec asparagus industry occupies the local market of fresh consumption and asparagus is typically one of many crops grown on mix production farms having less than 0.1 to 23 ha in cultivation (Table 1). Quebec asparagus fields are typically a fraction of a hectare in size. The proportion of the field area occupied by depopulated zones bordered with plants harboring lesions and yellow ferns typical of FCRR was visually estimated and rated as a percentage of field area affected. Two microsites with at least three asymptomatic or three symptomatic asparagus plants were chosen at each plantation site. At each microsite, a composite sample made of three 100 -g soil samples of each plant environment taken $20 \mathrm{~cm}$ from the plant (approximately $10 \mathrm{~m}$ apart) was collected from the top 0 to $15 \mathrm{~cm}$ of the soil with a probe. The proportion of sand, silt, and clay in the soil substrate was determined according to Sheldrick and Wang (24); soil nitrate $\left(\mathrm{NO}_{3}{ }^{-}\right)$and ammonium $\left(\mathrm{NH}_{4}{ }^{+}\right)$were determined by the method of Maynard and Karla (17); and soil available $\mathrm{P}, \mathrm{K}, \mathrm{Ca}, \mathrm{Mg}, \mathrm{Mn}, \mathrm{Cu}, \mathrm{Zn}$, and $\mathrm{Na}$ were extracted with Mehlich-3 solution (23). Soil pH was determined in water (13), and soil organic matter was determined by the method of weight loss-on-ignition (22).

Data analysis. Microenvironments with symptomatic plants and microenvironments with asymptomatic plants were compared using paired $t$ tests and found to be similar. Data from the microenvironments of symptomatic and asymptomatic plants were combined into a complete data set. Principal component analyses (PCAs) were conducted to explore the complete data set and to identify the variables potentially correlated with the percentage of field area affected by FCRR (14).

The PCAs for correlation matrices were sought, as variables had different units (14). One was set as the minimum Eigenvalue for factor consideration, as per Kaiser's rule. In the exploratory phase of data analysis, multiple PCA models were created successively using various sets of variables related to soil physicochemical characteristics, or crop management practices. This grouping was done to avoid placing excessive weight on soil nutrient influence by including soil fertility and fertilizationrelated variables in the same model. Numerical variables were selected for their level of influence on the plant-soil systems, as assessed by PCAs. The models best explaining the variance found in the data were used as indicators of relationships or absence of relationship between the percentages of field area affected by FCRR and soil characteristics or management-related variables. Soil organic matter was considered to be a management-related variable since, in light textured soils, organic matter level is largely influenced by site preparation, tillage intensity, and organic fertili-

TABLE 2. Soil physicochemical characteristics of symptomatic and asymptomatic microsites

\begin{tabular}{|c|c|c|c|c|c|c|}
\hline & \multirow[b]{3}{*}{ Min. } & \multirow[b]{3}{*}{ Max. } & \multicolumn{4}{|c|}{ Microenvironment with } \\
\hline & & & \multicolumn{2}{|c|}{ Symptomatic plants } & \multicolumn{2}{|c|}{ Asymptomatic plants } \\
\hline & & & Mean & $95 \% \mathrm{CI}^{\mathrm{a}}$ & Mean & $95 \% \mathrm{CI}^{\mathrm{a}}$ \\
\hline Clay $(\%)$ & 0.0 & 29.3 & 4.8 & 1.5 & 5.3 & 1.7 \\
\hline Silt $(\%)$ & 3.8 & 66.8 & 22.0 & 4.5 & 23.0 & 4.5 \\
\hline Sand $(\%)$ & 19.6 & 95.0 & 73.2 & 5.7 & 71.8 & 5.8 \\
\hline Soil organic matter $(\%)$ & 1.55 & 11.66 & 4.77 & 0.59 & 5.00 & 0.49 \\
\hline $\mathrm{pH}$ & 4.35 & 7.41 & 5.90 & 0.19 & 5.80 & 0.18 \\
\hline $\mathrm{NO}_{3}-\mathrm{N}\left(\mu \mathrm{g} \mathrm{g}^{-1}\right)$ & 6.3 & 225.5 & 32.8 & 9.4 & 33.9 & 10.2 \\
\hline $\mathrm{NH}_{4}-\mathrm{N}\left(\mu \mathrm{g} \mathrm{g}^{-1}\right)$ & 0.00 & 9.88 & 0.54 & 0.51 & 0.30 & 0.36 \\
\hline $\mathrm{P}\left(\mu \mathrm{g} \mathrm{g}^{-1}\right)$ & 57 & 844 & 284 & 49 & 284 & 54 \\
\hline $\mathrm{Na}\left(\mu \mathrm{g} \mathrm{g}^{-1}\right)$ & 0.00 & 22.49 & 5.57 & 1.41 & 5.70 & 1.64 \\
\hline $\operatorname{Mg}\left(\mu g g^{-1}\right)$ & 17 & 261 & 83 & 14 & 85 & 16 \\
\hline $\mathrm{K}\left(\mu \mathrm{g} \mathrm{g}^{-1}\right)$ & 51 & 591 & 244 & 38 & 264 & 37 \\
\hline $\mathrm{Ca}\left(\mu \mathrm{g} \mathrm{g}^{-1}\right)$ & 103 & 5,521 & 1,781 & 298 & 1,594 & 270 \\
\hline $\operatorname{Mn}\left(\mu \mathrm{g} \mathrm{g}^{-1}\right)$ & 1.4 & 59.6 & 14.8 & 3.18 & 14.8 & 2.8 \\
\hline $\mathrm{Fe}\left(\mu \mathrm{g} \mathrm{g}^{-1}\right)$ & 81 & 476 & 219 & 30 & 213 & 27 \\
\hline $\mathrm{Cu}\left(\mu \mathrm{g} \mathrm{g}^{-1}\right)$ & 0.10 & 10.00 & 1.87 & 0.43 & 1.99 & 0.50 \\
\hline $\mathrm{Zn}\left(\mu \mathrm{g} \mathrm{g}^{-1}\right)$ & 1.2 & 41.0 & 6.3 & 2.1 & 6.1 & 1.7 \\
\hline
\end{tabular}

a $95 \%$ confidence interval of the mean. 
zation, which was practiced to different degrees in $38 \%$ of the fields. The variables included with "percentage of field area affected by FCRR" in a model were unrelated as verified by correlation analysis when colinearity was suspected; when correlation occurred, the variable contributing best to model performance was retained and the other was rejected.

In a second step, the potential relationships between variables and percentage of area affected by FCRR, as revealed by PCA, were further examined by regression analyses. While PCA efficiently indicates where relationships could be found, this analysis gives little information on the nature of these potential relationships. Regression analysis was used to confirm relationships and give information on their nature and magnitude. Statistical analy-

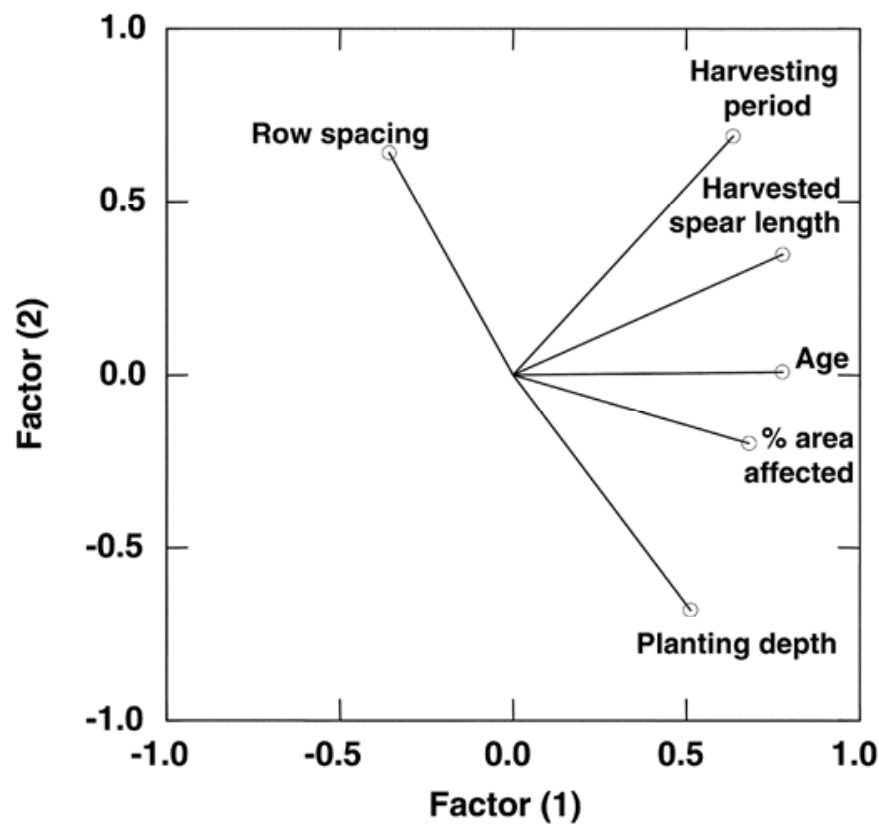

Fig. 1. Factor loading plot of the best solution of a principal component analysis conducted on the all-cultivar data, using crop management-related variables and the percentage of field area affected by Fusarium crown and root rot. Factor 1 explains $41.14 \%$ of the variance and factor 2 explains $25.16 \%$; cumulative variance explained $66.30 \%$. Eigenvalues are 2.47 for factor 1 and 1.51 for factor 2 . ses were conducted on the entire data set and on two subsets of the data that were related either to cv. Guelph Millenium or cv. Jersey Giant, the cultivars encountered most frequently in our study. All statistical analyses were conducted using the software Systat (version 9.1, Systat Software Inc., Richmond, CA).

\section{RESULTS}

The characteristics of soil microenvironments with symptomatic and asymptomatic plants were similar (Table 2). The soil environment varied extensively between fields, however, and potential association of variables with FCRR was investigated using PCA.

PCA of the six most significant crop management variables produced a two-factor model explaining $66.3 \%$ of the variance (Fig. 1). This model revealed positive relationships that were confirmed by regression analysis. There was no relationship between percentage of field affected by FCRR and row spacing, but percentage of field area affected by FCRR was correlated with both depth of planting $(P=0.004)$ (Fig. 2) and plantation age $(P<0.001)$ (Fig. 3A). Although these relationships were highly significant, their low correlation coefficient $\left(R^{2}=0.2333\right.$ for plantation age and $R^{2}=0.1112$ for planting depth) indicated that other factors also influenced the percentage of field area affected by FCRR.

Since different cultivars express different susceptibilities to FCRR (12), the data set also was analyzed by cultivar to avoid confounding effects of cultivar within plantation age (Fig. 3). The frequency of 'Guelph Millenium' (13 plantations) and 'Jersey Giant' (14 plantations) in our data set made it possible to search for the factors affecting FCRR expression within each of these cultivars. Furthermore, 'Guelph Millenium' and 'Jersey Giant' are particularly important because they are the cultivars currently used in new plantations. The use of the 'Guelph Millenium' and 'Jersey Giant' subsets, therefore, enabled the development of PCA models that explained more exactly the variation present in the data, justifying the parsing of the complete data set into cultivarrelated subsets. A PCA solution obtained from the analysis of the crop management variables of the data for 'Jersey Giant' revealed a relationship between plantation age and percentage of field area affected (Fig. 4A). This positive relationship was strong, supported by the high $R^{2}$ value of the polynomial relationship between these two variables (Fig. 3B) $\left(R^{2}=0.6806\right)$.

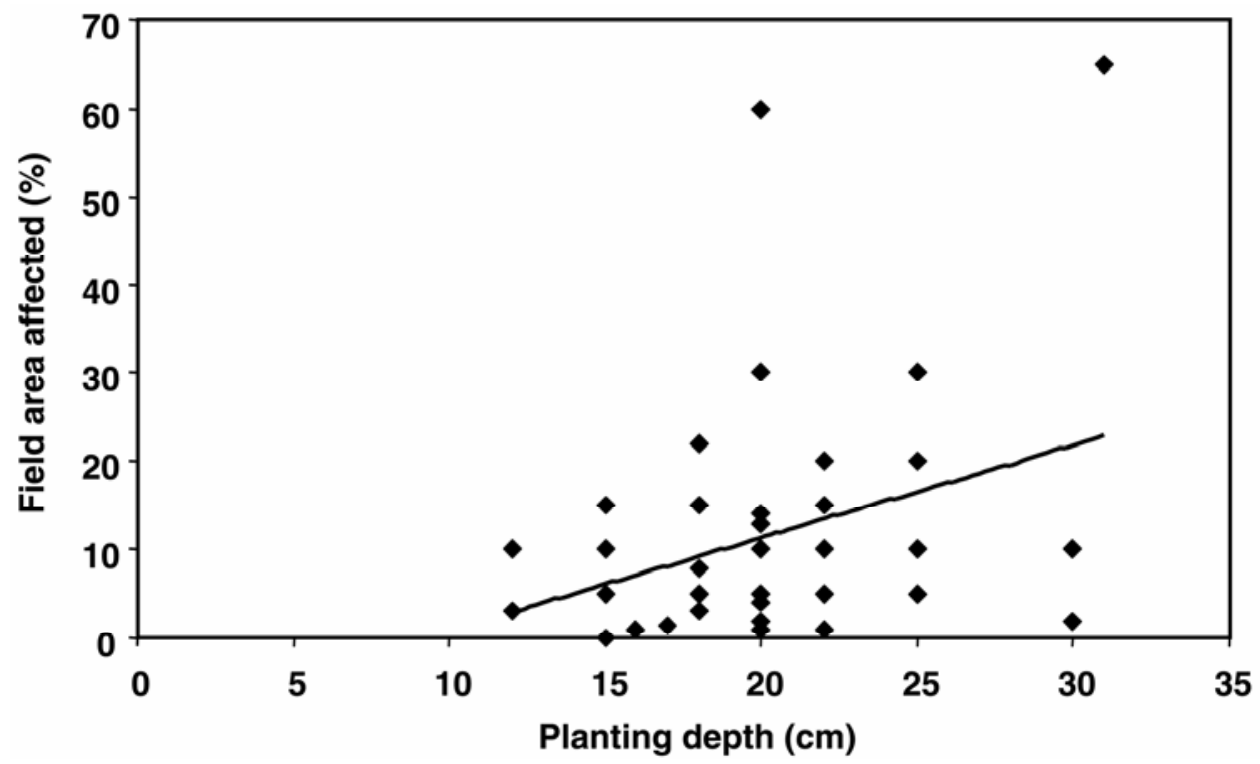

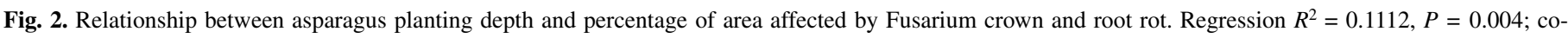
efficient $P<0.001$. 


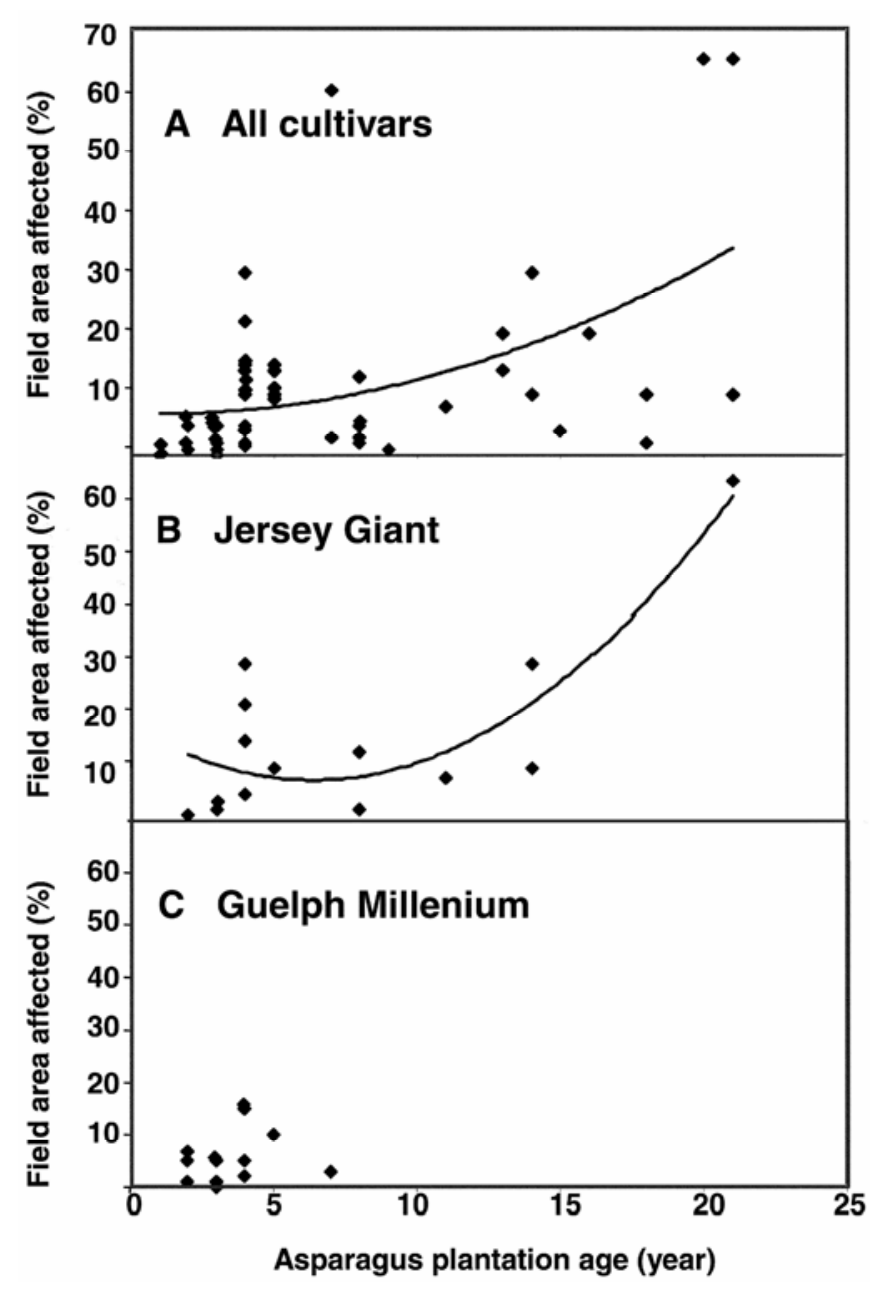

Fig. 3. Relationship between asparagus plantation age and percentage of area affected by Fusarium crown and root rot. A, Regression $R^{2}=0.2333, P<$ 0.001 ; coefficient $\mathrm{x}^{1}, P=0.002$; coefficient $\mathrm{x}^{2}, P=0.08$. B, Regression $R^{2}=$ $0.6806, P<0.001$; coefficient $\mathrm{x}^{1}, P<0.001$; coefficient $\mathrm{x}^{2}, P=0.001$. C, Regression nonsignificant.
The relationship suggests that FCRR progression is slow during the first few years after planting and progresses at an increasing rate as plantations age. It is important to note, however, that this relationship depended heavily on the observation associated with one highly affected 21-year-old field (Fig. 3B). Furthermore, several highly affected fields were likely destroyed as time went by, and hence, since older fields are obviously under-represented, the relationships presented in Figure $3 \mathrm{~A}$ and $\mathrm{B}$ probably underestimate FCRR development rate in the later part of the curve. On the contrary, the percentage of field area affected by FCRR was not related to plantation age in fields of 'Guelph Millenium' (Fig. 3C) probably because there was no 'Guelph Millenium' plantation older than 7 years; the 'Guelph Millenium' cultivar was released only recently.

PCA of the 'Jersey Giant' data subset pertaining to soil characteristic variables suggested an inverse relationship between the percentage of field area affected and the level of available soil $\mathrm{N}$ and $\mathrm{Mn}$, in a two-factor model involving eight variables, which explained $71.2 \%$ of the variance (Fig. 4B). Regression analysis did not support the negative relationship between nitrogen level and percentage of field area affected $(P=0.10)$, but confirmed the occurrence of a logarithmic relationship $(P<0.002)$ between field area affected and the level of available soil Mn (Fig. 5B). A relationship between field area affected by FCRR and soil available Mn was also found $(P<0.001)$ when the complete data set was submitted to regression analysis (Fig. 5A), but this relationship was not found in 'Guelph Millenium' fields (Fig. 5C), perhaps because the range of FCRR expression levels in 'Guelph Millenium' plantations was too small for this relationship to be revealed. Importantly, Mn availability was observed to decrease with plantation age as indicated by regression analysis. Again, the correlation existed when the whole data set $(P=0.002)$ (Fig. 6A) or only the 'Jersey Giant'-related data $(P=0.02)$ (Fig. 6B) were considered, but not when the 'Guelph Millenium' data were examined (Fig. 6C).

A three-factor PCA model involving seven crop managementrelated variables of the 'Guelph Millenium'-related data subset explained $86.8 \%$ of the variance (Fig. 7A). However, the factorloading plots of this best PCA solution did not indicate any clear relationship between FCRR and crop management-related variables. The absence of a significant relationship also was confirmed

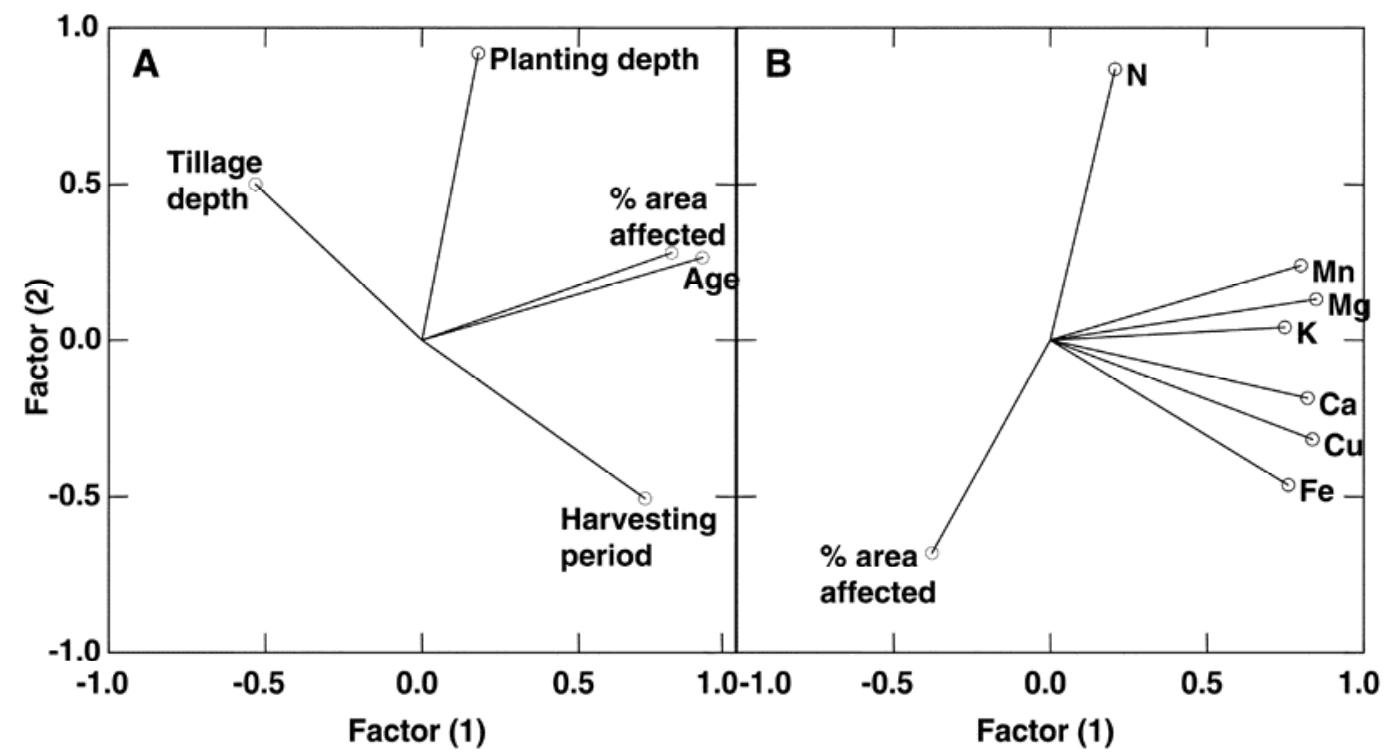

Fig. 4. Factor loading plots of the best solutions of principal component analyses conducted on the 'Jersey Giant' data. A, Relationship between crop managementrelated variables and the percentage of asparagus field area affected by Fusarium crown and root rot. Factor 1 explains $45.20 \%$ of the variance and factor 2 explains $29.97 \%$; cumulative variance explained $75.18 \%$. Eigenvalues are 2.26 for factor 1 and 1.50 for factor 2 . B, Relationship between variables related to soil characteristics and the percentage of asparagus field area affected by Fusarium crown and root rot. Factor 1 explains $50.71 \%$ of the variance and factor 2 explains $20.51 \%$; cumulative variance explained $71.23 \%$. Eigenvalues are 4.06 for factor 1 and 1.64 for factor 2. 
by regression analysis. Eight variables pertaining to soil characteristic in the 'Guelph Millenium'-related data subset produced a best PCA solution explaining $76.1 \%$ of the variance in a threefactor model (Fig. 7B). The latter model did not indicate any clear relationship between FCRR and soil characteristic variables. As for crop management-related variables, no significant relationship between the percentage of field area affected by FCRR and any soil characteristic variable could be found using regression analysis.

\section{DISCUSSION}

This unique study on association of cultural and edaphic factors with FCRR of asparagus in Quebec plantations revealed a number of significant although weak relationships, expressing the complexity of the asparagus field system and that of FCRR. It probably also reflects noise created by important influences on the systems, such as climate, which cannot be controlled. Investigations conducted in situ typically yield imprecise, but highly relevant, results. Soil Mn availability was negatively correlated with the percentage of field area affected by FCRR, suggesting an association between FCRR development and scarcity of soil available Mn. The absence of differences in soil Mn levels between

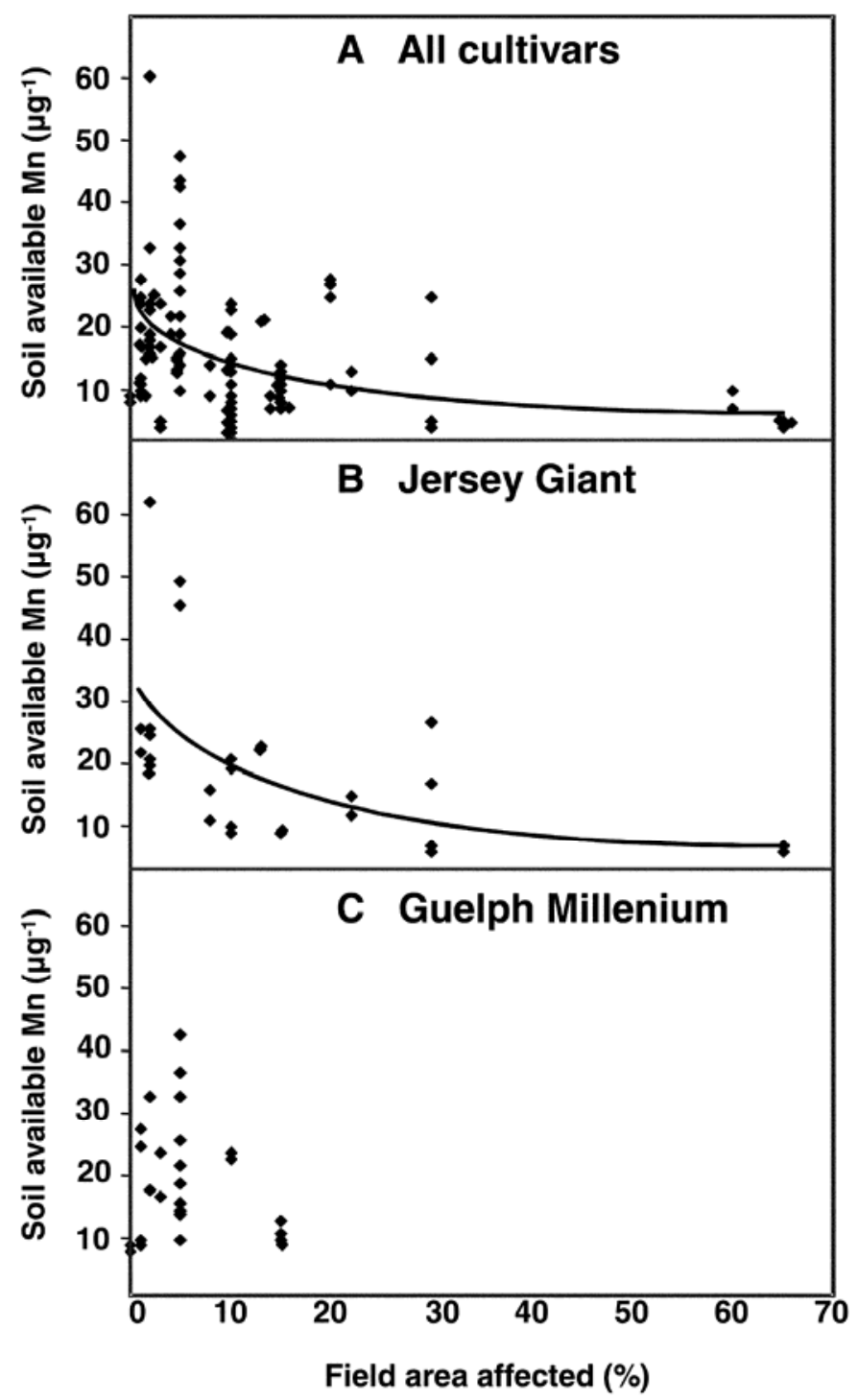

Fig. 5. Relationship between percentage of area affected by Fusarium crown and root rot and soil Mn availability in soil. A, Regression $R^{2}=0.1285, P<$ 0.001 ; coefficient $\mathrm{x}^{1}, P=0.001$; coefficient $\mathrm{x}^{2}, P=0.04$. B, Regression $R^{2}=$ $0.2910, P=0.002$; coefficient $\mathrm{x}^{1}, P=0.005$; coefficient $\mathrm{x}^{2}, P=0.01$. C, Regression nonsignificant. microplots with asymptomatic and with symptomatic plants, within fields, suggests that low Mn availability is conducive to FCRR outbreaks without being the cause of the disease. The negative correlation between available $\mathrm{Mn}$ and FCRR concurs with the conclusion of other studies $(6,10)$. In previous reports, the beneficial impact of $\mathrm{NaCl}$ application was associated with increased $\mathrm{Mn}$ availability. The reduction of FCRR severity with $\mathrm{NaCl}$ application was concurrent with an increase in the number of Mn-reducers in soil, mostly fluorescent pseudomonads but also some Serratia spp. In our study, we found that higher levels of available Mn were correlated with low percentages of field area affected by FCRR. We also have reported elsewhere (12) that a profound reorganization of microbial community structure occurred concurrently with the development of FCRR, in the soil of the asparagus plantations surveyed. This change in microbial community structure was associated with FCRR development. We did not quantify Mn-reducers in soil, but a shift in soil microbial community involving a decrease in the Mn-reducer population, as reported previously in fields of the United States (6), or conversely, an increase in Mn-oxidizers may have occurred. This would be in agreement with our observations of bacterial biodiversity shifts (12). Reports on the negative effects of phenolic acids produced by asparagus on soil microorganisms $(4,20)$ along with the appearance in this study of reduced soil Mn availability

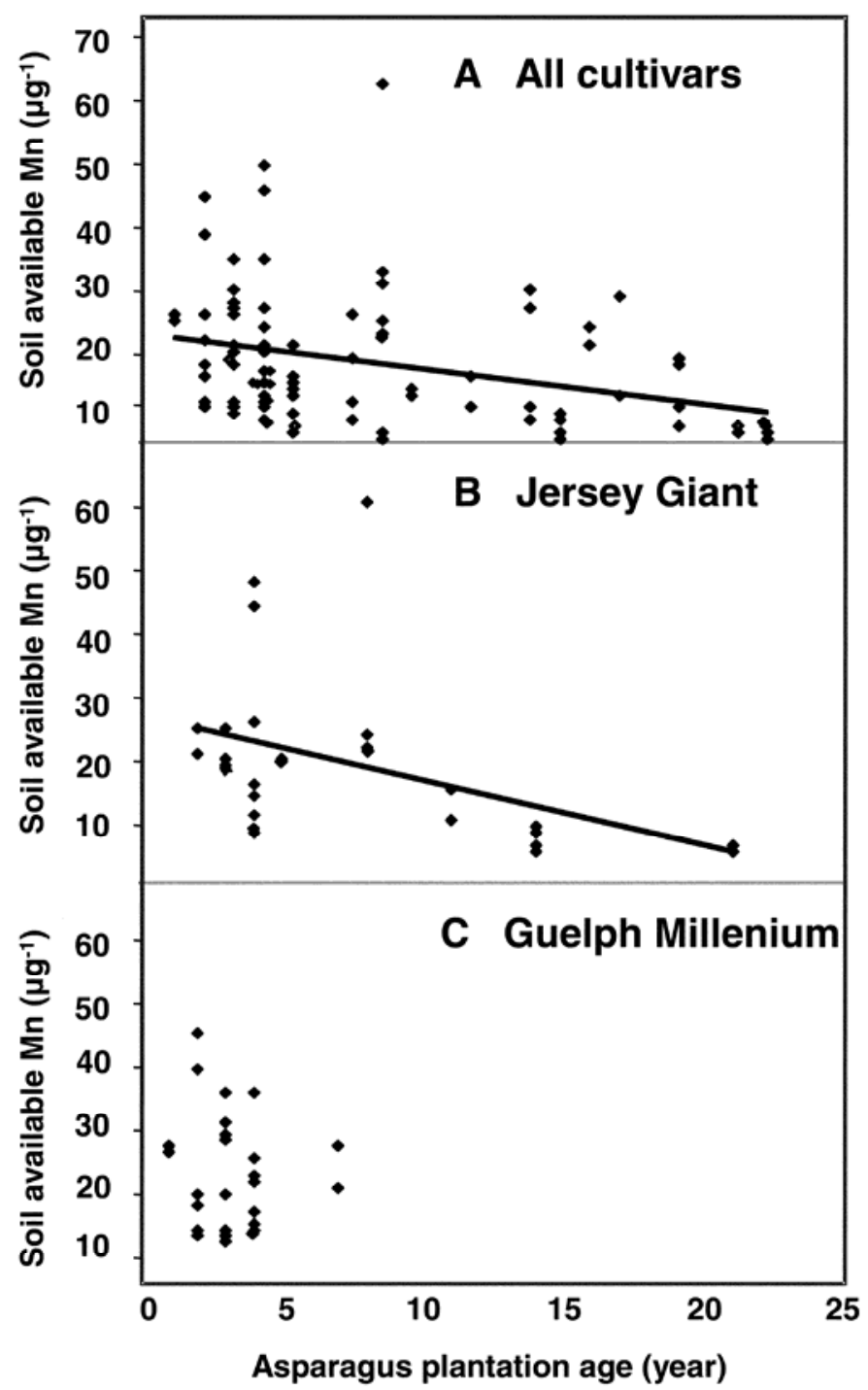

Fig. 6. Relationship between plantation age and soil available manganese. A, Regression $R^{2}=0.1044, P=0.002$; coefficient $\mathrm{x}^{1}, P<0.001$. B, Regression $R^{2}=0.1843, P<0.02$; coefficient $\mathrm{x}^{1}, P<0.001$. C, Regression nonsignificant. 
with increasing plantation age would rather suggest that asparagus exudates suppress Mn-reducers. Many Mn-reducing bacteria have disease suppressive characteristics in addition to increasing Mn availability in soil $(6,10)$. Thus, asparagus exudates might increase the conduciveness of soil toward FCRR.

The problem of FCRR would be alleviated by Mn fertilization if FCRR is simply related to the scarcity of soil available Mn. Application of Mn fertilizer to soil can have two effects. First, it can improve the Mn nutrition of plants and other soil inhabitants. Improved asparagus Mn nutrition may be important as suggested by the fact that reduced disease severity following $\mathrm{NaCl}$ application was associated with increased $\mathrm{Mn}$ in asparagus roots (10). Second, applications of Mn to soil could also reduce the negative impact of phenolic acids produced by asparagus as $\mathrm{Mn}$ was shown to be involved in the abiotic oxidation of phenolic compounds (16). Soil available Mn may enhance the destruction of toxic phenolics accumulating in soil under asparagus and thus increase the length of the productive period of asparagus plantations. The production of autotoxic compounds by asparagus roots is well documented $(2,15,30,31)$.

The causal agents of FCRR of asparagus are widespread in plantations, yet asparagus does not always express FCRR symptoms. Blok and Bollen (3) found F. oxysporum f. sp. asparagi in $69 \%$ of fields surveyed in asparagus growing regions of the Netherlands although these fields were never planted with asparagus. Only slight root rot symptoms could be seen, although most 1-year-old asparagus crowns from nurseries were infected with F. oxysporum f. sp. asparagi. In Northeastern United States, Elmer (8) surveyed asparagus sprouts sold in 22 markets of New Haven, CT, and found $F$. oxysporum and $F$. proliferatum, causal agents of FCRR, on the basal parts of $16.5 \%$ of the 1,776 spears examined. In our survey, pathogenic Fusarium spp., in particular $F$. oxysporum f. sp. asparagi and $F$. proliferatum, were found in all plantations on both asymptomatic and symptomatic plants (26). This suggests that FCRR expression requires the combined influence of pathogenic Fusarium strains and other factors, such as reduced Mn availability.

Outbreaks of FCRR may depend not only on inoculum distribution in the plantation soils but also on the susceptibility of individual plants. This susceptibility might vary from plant to plant of one cultivar as a consequence of the accumulation of autotoxic materials in soil or of stress from differential pressure of other pests (e.g., rust, which is also common in Quebec plantations). Overlapping multiple influences, each with low spatial heterogeneity, could result in enhanced overall spatial heterogeneity of conduciveness to FCRR; thus, the requirement of multiple factors for FCRR outbreaks would explain the patchiness of disease expression in the field.

Planting depth was also positively correlated with FCRR, but only when the whole data set was analyzed. This relationship had a low coefficient of determination $\left(R^{2}=0.1112\right)$, and hence, it is difficult to conclude with certainty that planting depth influenced the percentage of field area affected by FCRR. It is interesting to note, however, that a negative relationship between resistance to crown rot and depth of crown formation was reported in wheat (28). A similar effect of crown placement may also influence the success of pathogenic Fusarium in asparagus. The possibility of a planting depth effect on FCRR should be further investigated.

Soil $\mathrm{pH}$, texture, and drainage were not identified as factors affecting FCRR development in this study. This contrasts with a previous report indicating increased disease incidence in finetextured soils (19). Fine-textured soils are relatively nutrient rich, whereas coarse-textured soils are typically nutrient poor. Micronutrient deficiencies are more likely to occur in these latter soils (5). Hence, it may be worthwhile to revise the nutrient requirements of asparagus. Our observations indicate that, in particular, Mn fertilization and Mn uptake by asparagus should be examined in relation to disease severity. In low $\mathrm{pH}$ soils, FCRR is supposedly more severe (19). We did not observe any effect of $\mathrm{pH}$, although values ranged from 4.35 to 7.41 (Table 2). Thus, it appears that in Quebec asparagus fields, $\mathrm{pH}$ is not a factor determining the percentage of field area affected by FCRR.

Based on our results, a solution to FCRR may be found in the management of $\mathrm{Mn}$ availability in soil. Further investigation is needed to determine if Mn effect on FCRR proceeds through enhanced plant Mn nutrition or through an Mn-mediated enhancement of the degradation of phenolic acids in the soil under asparagus. It is also possible that the observed relation between $\mathrm{Mn}$ and FCRR simply reflects the importance of the negative impact of Mn-reducers on Fusarium in soil. In any case, planting depth should be kept shallow to prevent possible negative effects of deep planting.

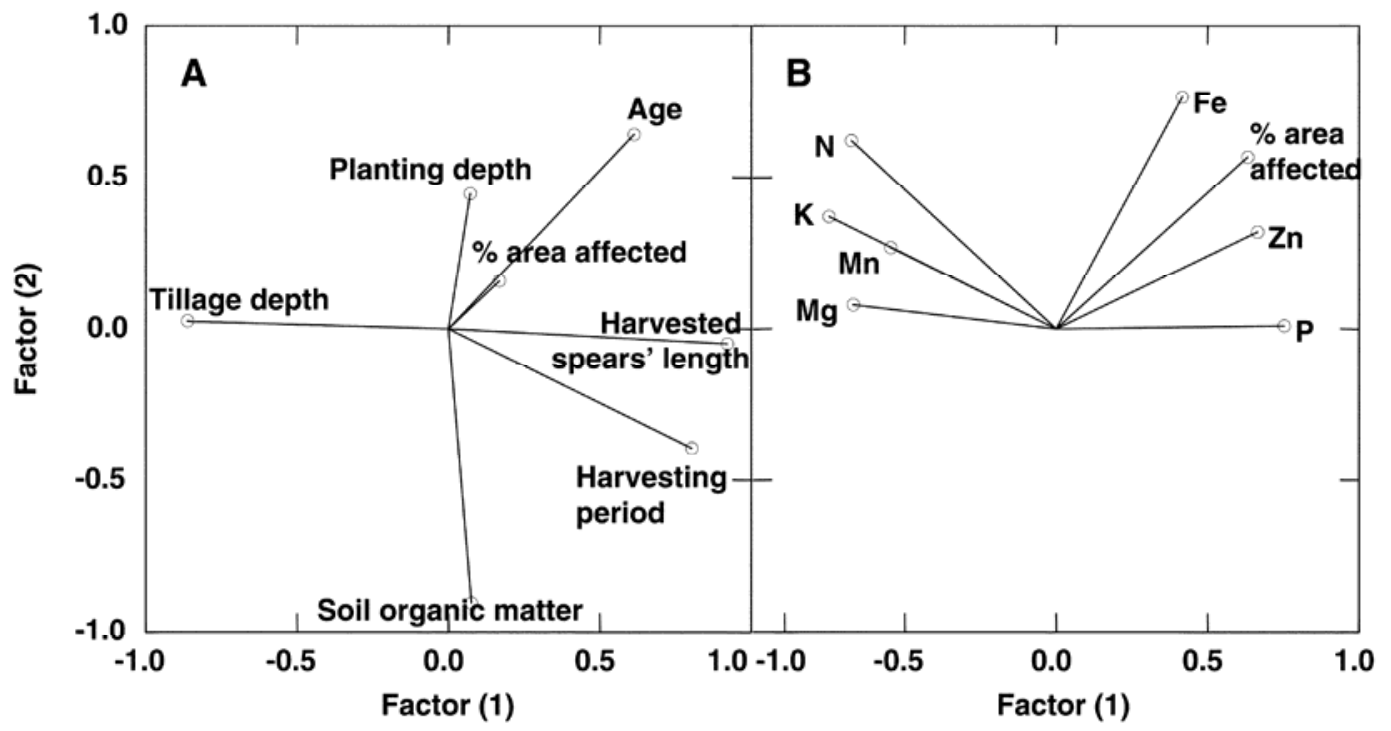

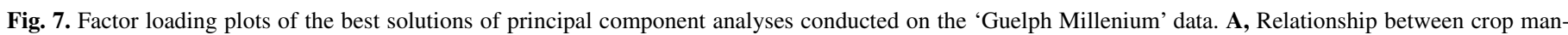

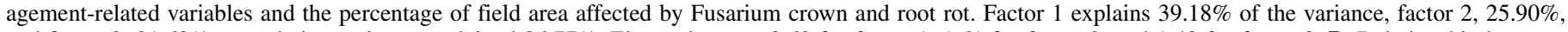

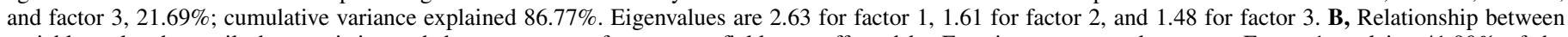

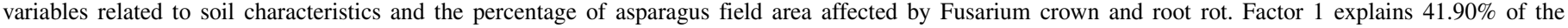

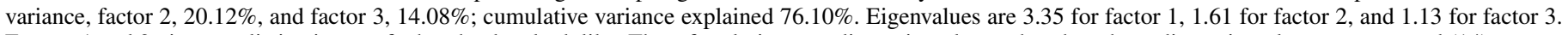
Factors 1 and 2 give a realistic picture of what the data look like. Thus, for clarity, two-dimension plots rather than three-dimension plots are presented (14). 


\section{ACKNOWLEDGMENTS}

This research was financially supported by the Conseil des recherches en pêches et agroalimentaire du Québec (CORPAQ) and by the Natural Science and Engineering Research Council of Canada (NSERC). This research would not have been possible without the collaboration of J.-G. Tessier and other agronomists of the Ministère de l'Agriculture des pêcheries et de l'alimentation du Québec. We thank the senior editor and the anonymous reviewers for their valuable comments.

\section{LITERATURE CITED}

1. Baayen, R. P. P., van den Boogert, P., Bonants, P. J. M., Poll, J. T. K., Blok, W. J., and Waalwijk, C. 2000. Fusarium redolens f. sp. asparagi, causal agent of asparagus root rot, crown rot and spear rot. Eur. J. Plant Pathol. 106:907-912.

2. Blok, W. J., and Bollen, G. J. 1993. The role of autotoxins from root residues of the previous crop in replant disease of asparagus. Neth. J. Plant Pathol. 99:29-40.

3. Blok, W. J., and Bollen, G. J. 1996. Inoculum sources of Fusarium oxysporum f. sp. asparagi in asparagus production. Ann. Appl. Biol. 128:219-231.

4. Blok, W. J., and Bollen, G. J. 1996. Interactions of asparagus root tissue with soil microorganisms as a factor in early decline of asparagus. Plant Pathol. 45:809-822.

5. Brady, N. C., and Weil, R. R. 2001. The Nature and Properties of Soils. 13th ed. Prentice Hall, Upper Saddle River, NJ.

6. Elmer, W. H. 1995. Association between Mn-reducing root bacteria and $\mathrm{NaCl}$ applications in suppression of Fusarium crown and root rot of asparagus. Phytopathology 85:1461-1467.

7. Elmer, W. H. 1996. Epidemiology and management of the diseases causal to asparagus decline. Plant Dis. 80:117-125.

8. Elmer, W. H. 2000. Incidence of infection of asparagus spears marketed in Connecticut by Fusarium spp. Plant Dis. 84:831-834.

9. Elmer, W. H. 2001. Fusarium diseases of asparagus. Pages 248-262 in: Fusarium: Paul E. Nelson Memorial Symposium. B. A. Summerell, J. F. Leslie, D. Backhouse, W. L. Bryden, and L. W. Burgess, eds. The American Phytopathological Society, St. Paul, MN.

10. Elmer, W. H. 2003. Local and systemic effects of $\mathrm{NaCl}$ on root composition, rhizobacteria, and Fusarium crown and root rot of asparagus. Phytopathology 93:186-192.

11. Gehlker, H., and Scholl, W. 1974. Ecological factors and cultivation problems in connection with parasitic root rot of asparagus. Z. Pflanzenk. Pflanzen. 81:394-406.

12. Hamel, C., Vujanovic, V., Jeannotte, R., Nakano, A., and St-Arnaud, M. Negative feedback on a perennial crop, Fusarium crown and root rot of asparagus is related to changes in soil microbial community structure. Plant Soil (In press).

13. Hendershot, W. H., Lalande, H., and Duquette, M. 1993. Soil reaction and exchangeable acidity. Pages 141-146 in: Soil Sampling and Methods of Analysis. M. Carter, ed. CRC Press, Boca Raton, FL.
14. Jolliffe, I. T. 2002. Principal Component Analysis. 2nd ed. SpringerVerlag, New York.

15. Lake, R. J., Falloon, P. G., and Cook, D. W. M. 1993. Replant problem and chemical components of asparagus roots. N.Z. J. Crop Hortic. Sci. 21:53-58.

16. Lequart, C., Kurek, B., Debeire, P., and Monties, B. 1998. $\mathrm{MnO}_{2}$ and oxalate: An abiotic route for the oxidation of aromatic components in wheat straw. J. Agric. Food Chem. 46:3868-3874.

17. Maynard, D. G., and Karla, Y. P. 1993. Nitrate and exchangeable ammonium nitrogen. Pages 25-38 in: Soil Sampling and Methods of Analysis. M. Carter, ed. CRC Press, Boca Raton, FL.

18. Nelson, P. E., Toussoun, T. A., and Cook, R. J. (eds.) 1981. Fusarium: Diseases, Biology and Taxonomy. Pennsylvania State University Press, University Park, PA.

19. Nonnecke, I. L. 1989. Vegetable Production. VanNostrand Reinhold, New York.

20. Pederson, C. T., Safir, G. R., Siqueira, J. O., and Parent, S. 1991. Effect of phenolic compounds on asparagus mycorrhiza. Soil Biol. Biochem. 23:491-494.

21. Reid, T. C., Hausbeck, M. K., and Kizilkaya, K. 2001. Effects of sodium chloride on commercial asparagus and of alternative forms of chloride salt on Fusarium crown and root rot. Plant Dis. 85:1271-1275.

22. Schulte, E. E., Kaufmann, C., and Peter, J. B. 1991. The influence of sample size and heating time on soil weight loss-on-ignition. Commun. Soil Sci. Plan. 22:159-168.

23. Sen Tran, T., and Simard, R. R. 1993. Mehlich III-extractable elements. Pages 43-50 in: Soil Sampling and Methods of Analysis. M. Carter, ed. CRC Press, Boca Raton, FL.

24. Sheldrick, B. H., and Wang, C. 1993. Particle size distribution. Pages 499512 in: Soil Sampling and Methods of Analysis. M. Carter, ed. CRC Press, Boca Raton, FL.

25. Vujanovic, V., Hamel, C., Jabaji-Hare, S., and St-Arnaud, M. 2002. Development of a selective myclobutanil agar medium (MBA) for the isolation of Fusarium species from asparagus fields. Can. J. Microbiol. 48:841-847.

26. Vujanovic, V., Hamel, C., Yergeau, E., and St-Arnaud, M. Mycodiversity and mycogeography of Fusarium species from northeastern North American asparagus fields, based on microbiological and molecular approaches. Microbial Ecol. (In press).

27. Warncke, D. D., Reid, T. C., and Hausbeck, M. K. 2002. Sodium chloride and lime effects on soil cations and elemental composition of asparagus fern. Commun. Soil Sci. Plan. 33:3075-3084.

28. Wildermuth, G. B., McNamara, R. B., and Quick, J. S. 2001. Crown depth and susceptibility to crown rot in wheat. Euphytica 122:397405.

29. Yergeau, E., Filion, M., Vujanovic, V., and St-Arnaud, M. 2005. A PCRdenaturing gradient gel electrophoresis (DGGE) approach to assess Fusarium diversity in asparagus. J. Microbiol. Methods 60:143-154.

30. Young, C. C., and Chen, S. H. 1987. Phytotoxic study in the soil and root exudates of Asparagus officinalis L. Asparagus Res. News. 5:55-56.

31. Young, C. C., and Chou, T. C. 1985. Autointoxication in residues of Asparagus officinalis L. Plant Soil 85:385-393. 